\title{
PROGNOZA DEMOGRAFICZNA DLA OBSZARÓW WIEJSKICH WOJEWÓDZTWA DOLNOŚLĄSKIEGO DO 2020 R.
}

\author{
POPULATION PROJECTION FOR RURAL AREAS \\ OF THE DOLNOŚLĄSKIE VOIVODSHIP BY 2020
}

\author{
Stanisława GÓRECKA ${ }^{1} \bullet$ Robert SZMYTKIE ${ }^{1} \bullet$ Wojciech MALESZKA ${ }^{2}$ \\ ${ }^{1}$ Uniwersytet Wrocławski Instytut Geografii i Rozwoju Regionalnego \\ pl. Uniwersytecki 1, 50-137 Wrocław \\ stanisława.gorecka@uni.wroc.pl•robert.szmytkie@uni.wroc.pl \\ ${ }^{2}$ Instytut Rozwoju Terytorialnego we Wrocławiu \\ ul. Świdnicka 12-16, 50-068 Wrocław \\ wojciech.maleszka@irt.wroc.pl
}

Zarys treści: Celem opracowania jest analiza wyników prognozy demograficznej dla gmin województwa dolnośląskiego do 2020 r. Przewiduje się, że do 2020 r. liczba mieszkańców województwa zmniejszy się o 36,8 tys. osób. Największe bezwzględne ubytki liczby ludności wystąpią w największych miastach regionu, natomiast liczba ludności obszarów wiejskich na Dolnym Śląsku wzrośnie o 23,3 tys. osób. Obszary wiejskie w województwie cechują się znacznym zróżnicowaniem prognozowanych trendów zmian demograficznych: wzrost liczby ludności w gminach podmiejskich, stagnacja lub spadek liczby mieszkańców w pozostałych jednostkach. Przestrzenne zróżnicowanie trendów zmian demograficznych przyczyni się do zmian w rozmieszczeniu ludności. W skali regionu nastąpi wzrost koncentracji ludności w obrębie Wrocławskiego Obszaru Funkcjonalnego, natomiast w układach lokalnych będzie miała miejsce dekoncentracja ludności, wywołana procesami suburbanizacji.

Słowa kluczowe: zmiany ludnościowe, prognoza demograficzna, obszary wiejskie, Dolny Śląsk.

\section{Wprowadzenie}

Potencjał demograficzny jest jednym z głównych czynników wpływających na rozwój społeczno-gospodarczy. Znaczenie potencjału demograficznego jest szczególnie istotne w odniesieniu do systemu edukacji i rynku pracy, którego funkcjonowanie w dużym stopniu zależy od zasobów siły roboczej. W obliczu ogólnie niekorzystnej sytuacji ludnościowej kraju wzrosło znaczenie zagadnienia bezpieczeństwa demograficznego, zwłaszcza w odniesieniu do regionów charakteryzujących się szczególnie niekorzystnymi trendami zmian ludnościowych. Przykładem takiego regionu jest województwo dolnośląskie, które na tle kraju wyróżnia się niskim poziomem konkurencyjności potencjału demograficznego, na co złożyły się zwłaszcza niekorzystne trendy w ruchu naturalnym ludności oraz pogarszająca się sukcesywnie struktura demograficzna ludności. Województwo charakte- 
ryzuje się ponadto dużym zróżnicowaniem przestrzennym potencjału demograficznego, co kształtowane jest głównie przez trend zmian ludnościowych na obszarach wiejskich (por. Brezdeń i in. 2012). Podczas gdy miasta Dolnego Śląska w większości podlegają intensywnym procesom kurczenia się (Krzysztofik i Szmytkie 2011), tak obszary wiejskie województwa cechują się zróżnicowaną sytuacją demograficzną, zależną od odległości od głównych ośrodków miejskich regionu, co związane jest z procesami suburbanizacji (Mayer i Szmytkie 2014). W tym kontekście szczególnie istotne wydaje się określenie przyszłych trendów zmian ludnościowych, które będą wpływały na rozwój społeczno-gospodarczy obszarów wiejskich województwa dolnośląskiego w perspektywie najbliższych lat. Znaczenie prognoz demograficznych w planowaniu rozwoju społeczno-gospodarczego w skali lokalnej dostrzeżone zostało przez Instytut Rozwoju Terytorialnego we Wrocławiu, który zlecił opracowanie prognozy demograficznej dla gmin województwa dolnośląskiego do 2035 r. W niniejszym opracowaniu prezentowane są wyniki prognozy do 2020 r. (czyli w krótkim horyzoncie czasowym), przy czym szczególny nacisk położono na analizę trendów przyszłych zmian ludnościowych na obszarach wiejskich województwa. Prognoza została opracowana dla ludności faktycznie zamieszkałej w poszczególnych gminach (ogółu osób zameldowanych na pobyt stały w danej jednostce i rzeczywiście tam zamieszkałych oraz osób przebywających czasowo i zameldowanych w tej jednostce na pobyt czasowy ponad 3 miesiące). W szacowaniu przyszłej liczby ludności według płci i wieku uwzględniono naturalne przesunięcia kohort oraz przewidywane zmiany w zakresie ruchu naturalnego (urodzeń i zgonów) oraz migracji (wewnętrznych i zagranicznych). Przewidywane trendy w zakresie płodności i umieralności opracowano na podstawie założeń opublikowanej w 2011 r. przez GUS Prognozy dla powiatów i miast na prawie powiatu oraz podregionów na lata 2011-2035. Prognozę demograficzną dla gmin sporządzono w jednym, najbardziej realistycznym wariancie (analogicznie jak w prognozie GUS dla powiatów).

Podstawowym problemem metodologicznym w sporządzaniu prognozy dla gmin była zbyt mała liczebność ich populacji (w większości przypadków dotyczyło to gmin wiejskich i miejsko-wiejskich). Dane retrospektywne z okresu 1995-2013, które przeanalizowano w trakcie opracowywania założeń prognozy, w wielu gminach wykazywały bardzo dużą zmienność liczby urodzeń (a także struktury urodzeń według płci) oraz napływu i odpływu migracyjnego pomiędzy kolejnymi latami. Jest to zjawisko typowe dla małych populacji, gdzie roczne wahania losowe liczby urodzeń i salda migracji mogą powodować skokowe zmiany w liczebności niektórych roczników (szczególnie najmłodszych oraz tych, które wyróżniają się największą aktywnością migracyjną). Podobne wahania losowe mogą mieć także miejsce w przyszłości.

\section{Metoda}

W sporządzaniu prognozy zastosowano metodę kohortowo-składnikową (ryc. 1), która polega na:

1) naturalnych przesunięciach poszczególnych kohort w czasie,

2) przewidywaniu (prognozowaniu) kolejnych składników dynamiki ludności:

- płodności,

- umieralności,

- salda migracji. 
$\mathrm{t}=1$

Początkowa $(\mathrm{t}=0)$ struktura ludności według wieku (x) i płci (s) $L(x, s, 0)$

Initial $(t=0)$ structure of population

according to age $(x)$ and sex (s) $P(x, s, 0)$

$t=2$

Struktura ludności według wieku $(\mathrm{x}$

i płci (s) na końcu okresu ( $t=1$ )

$$
L(x, s, 1)
$$

Age $(x)$ and sex (s) structure of the population at the end of the interval $(t=1)$ $P(x, s, 1)$

-

$\bullet$

$\mathrm{t}=\mathrm{n}$

Struktura ludności według wieku $(\mathrm{x})$

i płci (s) na końcu okresu ( $\mathrm{t}=\mathrm{n}-1)$

$$
\mathrm{L}(\mathrm{x}, \mathrm{s}, \mathrm{n}-1)
$$

Age $(x)$ and sex (s) structure of the

population at the end of the interval $(t=n-1)$ $P(x, s, n-1)$

Ryc. 1. Metoda kohortowo-składnikowa

Cohort-component method

Źródło/Source: J. Kurkiewicz (2010). korekta stanu ludności ze wzgledu na migracje

correction of the population state on grounds of migrations

- postarzanie ludności, wyznaczanie liczby zgonów

ageing of population, calculation of the number of deaths

kreślenie liczby urodzen

calculation of the number of births

- korekta stanu ludności ze względu na migracje

correction of the population state on grounds of migrations

- postarzanie ludności, wyznaczanie liczby zgonów

ageing of population, calculation of the number of deaths

- określenie liczby urodzeń

calculation of the number of births

\section{$\bullet$}

- korekta stanu ludności ze względu na migracje

correction of the population state on grounds of migrations

- postarzanie ludności, wyznaczanie liczby zgonów

ageing of population, calculation of the number of deaths

- określenie liczby urodzeń

calculation of the number of births
Struktura ludności według wieku (x) i płci (s) na końcu okresu $(t=1)$

$$
\mathrm{L}(\mathrm{x}, \mathrm{s}, 1)
$$

CStructure of population according to age $(x)$ and sex (s) at the end of the interval $(t=1)$ $P(x, s, 1)$ 
Prognoza demograficzna obejmowała następujące etapy (Holzer 2003; Kurkiewicz 2010):

1) ustalenie wyjściowego stanu i struktury ludności (według płci, wieku i miejsca zamieszkania w podziale na miasto i wieś),

2) określenie i uwzględnienie efektów przyszłych ruchów migracyjnych w strukturze ludności według płci i wieku,

3) ustalenie poziomu umieralności (prawdopodobieństw przeżycia),

4) postarzanie ludności żyjącej,

5) ustalenie poziomu cząstkowych współczynników płodności,

6) szacowanie liczby urodzeń według płci w każdym roku objętym horyzontem prognozy,

7) obliczenie wynikowych współczynników demograficznych.

\section{Założenia prognozy}

\section{Stan ludności}

Podstawę prognozy demograficznej dla gmin stanowiły dane GUS o liczbie i strukturze ludności według płci i wieku w poszczególnych gminach miejskich, wiejskich i miejskowiejskich zgodnie ze stanem na dzień 31.12.2013 r. pozyskane z Bazy Demografia. Prognoza została policzona oddzielnie dla każdej gminy, wyniki dla powiatów stanowią sumę stanów ludności w poszczególnych gminach.

\section{Umieralność}

Prognozę liczby zgonów w gminach w poszczególnych latach objętych horyzontem prognozy oszacowano w oparciu o prawdopodobieństwa przeżycia, obliczone na podstawie tablic trwania życia. Ze względu na nieudostępnianie przez GUS pełnych wojewódzkich tablic trwania życia, do obliczeń przyjęto parametry trwania życia z tablic ogólnopolskich (Trwanie życia w 2013 r., GUS, Warszawa 2014). Prawdopodobieństwa przeżycia dla poszczególnych przekrojów czasowych obliczono odrębnie dla kobiet i mężczyzn z dodatkowym uwzględnieniem charakteru miejsca zamieszkania: gminy miejskie, wiejskie i miejsko-wiejskie.

\section{Rozrodczość}

Przewidywaną liczbę urodzeń w poszczególnych gminach w roku wyjściowym prognozy (2014) obliczono na podstawie danych faktycznych z urodzeń w latach 20112013. Do oszacowania liczby urodzeń w kolejnych latach objętych horyzontem prognozy wykorzystano założenia dotyczące trendu zmian w poziomie dzietności kobiet dla województwa dolnośląskiego zawarte w Prognozie dla powiatów i miast na prawie powiatu oraz podregionów na lata 2011-2035. W oparciu o te dane obliczono trendy dzietności dla poszczególnych powiatów, odrębnie dla gmin miejskich, wiejskich i miejsko-wiejskich.

\section{Migracje wewnętrzne}

W celu oszacowania przyszłych strumieni napływu i odpływu w migracjach wewnętrznych na pobyt stały przeprowadzono analizę charakteru, dynamiki i zmian ruchów migracyjnych w latach 2004-2008 i 2009-2013 (na podstawie Banku Danych Lokalnych GUS). Analizowane jednostki podzielono na trzy grupy: gminy miejskie, gminy w strefach podmiejskich oraz pozostałe gminy miejsko-wiejskie i wiejskie, dla których opracowano odmienne warianty ruchów migracyjnych, uwzględniając różną dynamikę 
napływu i odpływu ludności w poszczególnych gminach. Strukturę migrantów wg płci i wieku w przekroju: gminy miejskie, gminy miejsko-wiejskie i gminy wiejskie opracowano w oparciu o tabelę Migracje wewnętrzne na pobyt stały według kierunków i wieku migrantów w 2012 r. zawartą Roczniku demograficznym 2013.

\section{Migracje zagraniczne}

Wielkość napływu i odpływu w migracjach zagranicznych na pobyt stały oszacowano na podstawie współczesnych ogólnopolskich trendów zmian liczby imigrantów i emigrantów, zakładając nieznaczny, stały wzrost ich liczby, nawiązujący do wzrastającej mobilności ludności w ostatnich latach. Strukturę migrantów wg płci i wieku w przekroju: gminy miejskie, gminy miejsko-wiejskie i gminy wiejskie opracowano w oparciu o tabelę Migracje zagraniczne na pobyt stały według płci i wieku migrantów w 2012 r. zawartą Roczniku demograficznym 2013.

\section{Zmiany ludnościowe na obszarach wiejskich Dolnego Śląska do 2020 r.}

Przewiduje się, że do 2020 r. liczba ludności województwa dolnośląskiego zmniejszy się o 36,8 tys. osób (czyli o 1,26\%). Największe bezwzględne ubytki liczby mieszkańców wystąpią w największych miastach regionu, tzn. w Wałbrzychu (o 7,4 tys. osób), Wrocławiu (o 5,9 tys.), Lubinie (o 5,3 tys.), Jeleniej Górze (o 4,5 tys.), Legnicy (o 3,6 tys.), Głogowie (o 3,5 tys.) i Świdnicy (o 3,2 tys.). W analizowanym okresie miasta Dolnego Śląska stracą ok. 60 tys. mieszkańców (o 2,97\%). Tak znaczne ubytki liczby ludności w miastach regionu będą wywołane głównie niekorzystnymi trendami w zakresie ruchu naturalnego (zwłaszcza malejącą z roku na rok liczbą urodzeń) i pogłębiającymi się tendencjami suburbanizacyjnymi, które przyczyniają się do ujemnego salda migracji w miastach. Wzrost liczby mieszkańców wystąpi jedynie w 11 ośrodkach miejskich, w szczególności w miastach leżących w strefie bezpośredniego oddziaływania Wrocławia. W tym czasie liczba ludności obszarów wiejskich w województwie wzrośnie o 23,3 tys. osób (o 2,61\%). Przyczyni się to do zmniejszenia się udziału ludności miejskiej z 69,4\% w 2013 r. do 68,2\% w 2020 r.

Obszary wiejskie na Dolnym Śląsku cechują się ponadto znacznym zróżnicowaniem prognozowanych trendów zmian demograficznych (ryc. 2). Wśród gmin wiejskich i wiejskich części gmin miejsko-wiejskich w województwie największy wzrost liczby ludności do 2020 r. wystąpi w gminach podmiejskich. W otoczeniu Wrocławia są to gminy Czernica (o 21,30\%), Siechnice (o 20,31\%), Długołęka (o 17,10\%), Żórawina (o 14,71\%) i Miękinia (o 13,65\%), a w sąsiedztwie głównych ośrodków Legnicko-Głogowskiego Obszaru Funkcjonalnego gminy: Jerzmanowa (o 19,99\%), Lubin (o 18,37\%), Polkowice (o 14,92\%) i Kunice (o 14,15\%). Znaczące wzrosty liczby mieszkańców wystąpią również w strefach podmiejskich innych miast, np. Jeleniej Góry (gmina wiejska Jeżów Sudecki), Świdnicy (gmina wiejska Świdnica), Zgorzelca (gmina wiejska Zgorzelec) czy Bolesławca (gminy wiejskie Bolesławiec i Warta Bolesławiecka). W sumie w 41 gminach wiejskich województwa dolnośląskiego wystąpi wzrost liczby ludności (wzrost o co najmniej 0,2\% rocznie). Za wzrost liczby mieszkańców w strefach podmiejskich odpowiedzialny będzie głównie napływ migracyjny z pobliskich miast. Prowadzić będzie to nie tylko do przyrostu liczby ludności, ale także do zmian w strukturach ludności gmin podmiejskich (przede wszystkim do ich odmłodzenia w wyniku napływu ludności w wieku produkcyjnym mobilnym) oraz wzrostu liczby urodzeń. 


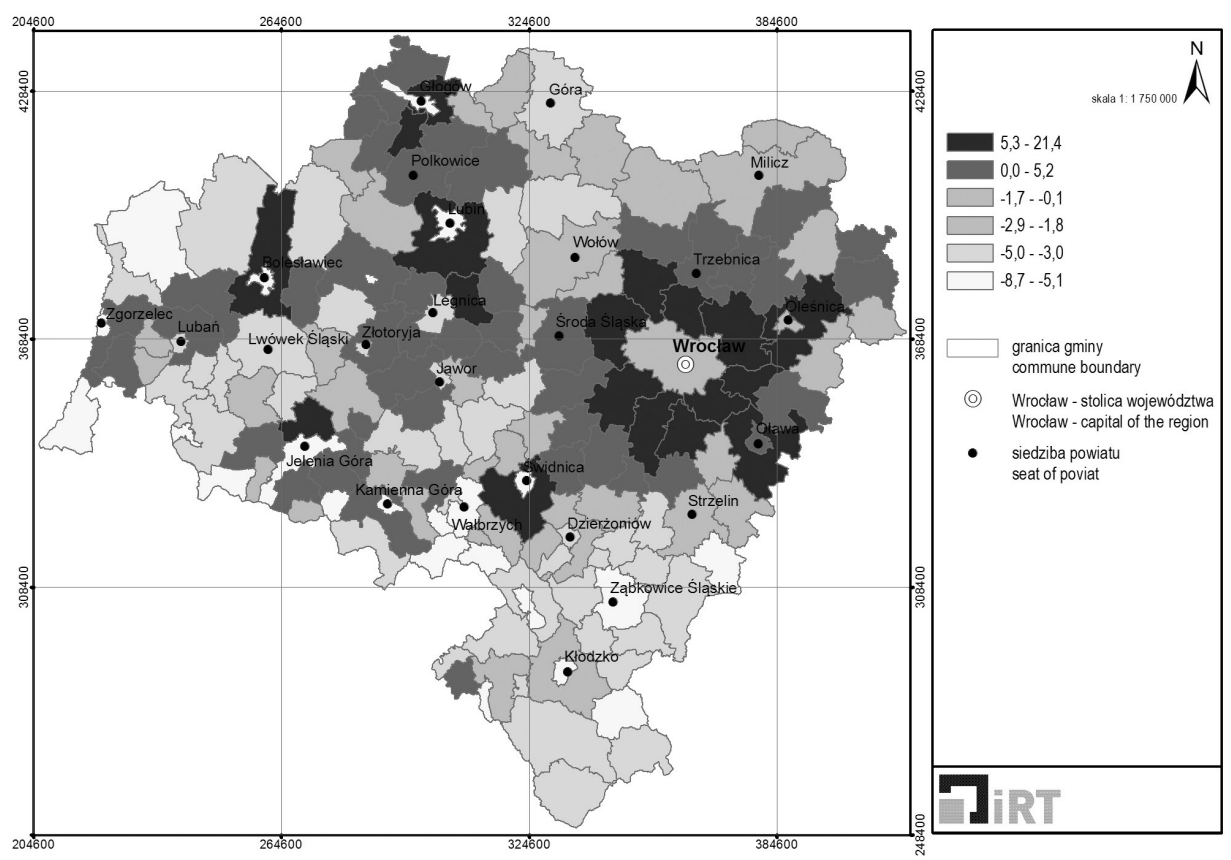

Ryc. 2. Zmiany liczby ludności w gminach województwa dolnośląskiego w latach 2013-2020 (\%) Population changes in communes of the Dolnoślqskie Voivodship in the years 2013-2020 (\%) Źródło/Source: opracowanie własne/own elaboration.

W 35 gminach wiejskich i wiejskich częściach gmin miejsko-wiejskich województwa będzie miała miejsce stagnacja liczby mieszkańców (zmiany liczby ludności w zakresie od $-0,2 \%$ do $+0,2 \%$ rocznie), a w pozostałych 55 jednostkach wystąpi wyraźny spadek liczby ludności, największy w gminach sudeckich i podsudeckich, jak np. Bogatynia (o 9,29\%), Głuszyca (o 8,67\%), Stronie Śląskie (o 6,96\%), Mieroszów (o 6,86\%) i Złoty Stok (o 6,56\%). Za ubytek liczby ludności w tych gminach będą odpowiedzialne zarówno niekorzystne trendy w ruchu naturalnym, jak i ujemne saldo migracji. Niekorzystną sytuacją demograficzną będą cechowały się również gminy wiejskie położone peryferyjnie względem głównych ośrodków miejskich w województwie, jak np. Przeworno, Udanin, Ciepłowody i Stoszowice.

\section{Główne tendencje zmian demograficznych i ich skutki}

Spadek liczby mieszkańców w województwie dolnośląskim będzie spowodowany głównie niekorzystnymi zmianami w zakresie poziomu rozrodczości. Mimo prognozowanego wzrostu dzietności kobiet, liczba urodzeń w województwie będzie systematycznie spadać, jako efekt niekorzystnych zmian w strukturze ludności według wieku, które powstały w latach 90. XX w. i na początku lat 2000. Do spadku liczby ludności województwa przyczyniać się będzie ponadto liczba zgonów, która będzie się systematycznie zwiększać, pomimo prognozowanego wzrostu przeciętnego trwania życia Dolnoślązaków. Będzie to efekt postępującego procesu starzenia demograficznego, pogłębianego wchodze- 
niem w wiek emerytalny dużych liczebnie roczników urodzonych w powojennym wyżu kompensacyjnym.

Ujemnej wartości przyrostu naturalnego nie będzie w stanie skompensować napływ migracyjny ludności. Wprawdzie wielkości salda migracji przewidywane do 2020 r. będą dla całego województwa dodatnie, to sytuacja taka nie będzie jednak dotyczyć terytorium całego województwa, a jedynie Wrocławskiego Obszaru Funkcjonalnego. Przyrost migracyjny przyczyniać się tam będzie do względnie korzystnej sytuacji demograficznej (relatywnie dużego udziału ludności w wieku przedprodukcyjnym i niskiego udziału ludności w wieku poprodukcyjnym - ryc. 3 i 4). Większość gmin w województwie będzie się natomiast borykała z pogłębiającym się procesem starzenia demograficznego. Problem ten będzie w szczególności dotyczył miast i gmin leżących w sudeckiej części województwa. W niektórych gminach udział ludności w wieku poprodukcyjnym w 2020 r. przekroczy 26\% (Lądek-Zdrój, Stronie Śląskie, Bystrzyca Kłodzka). Regionalne zróżnicowanie procesów demograficznych będzie w głównej mierze efektem różnic w zakresie mobilności przestrzennej ludności.

Przestrzenne zróżnicowanie trendów zmian demograficznych przyczyni się do zmian w rozmieszczeniu ludności. W skali regionu nastąpi wzrost koncentracji ludności w obrębie Wrocławskiego Obszaru Funkcjonalnego z 35,9\% w 2013 r. do 37,1\% w 2020 r., natomiast w układach lokalnych (miejskie obszary funkcjonalne, lokalne zespoły osadnicze) będzie miała miejsce dekoncentracja ludności, wywołana procesami suburbanizacji, przejawiającymi się odpływem ludności z miast do gmin podmiejskich. Najbardziej znaczące zmiany wystąpią we Wrocławskim Obszarze Funkcjonalnym, gdzie udział mieszkańców Wrocławia w stosunku do ogółu ludności WrOF spadnie z 60,4\% w 2013 r. do 58,8\% w 2020 r.

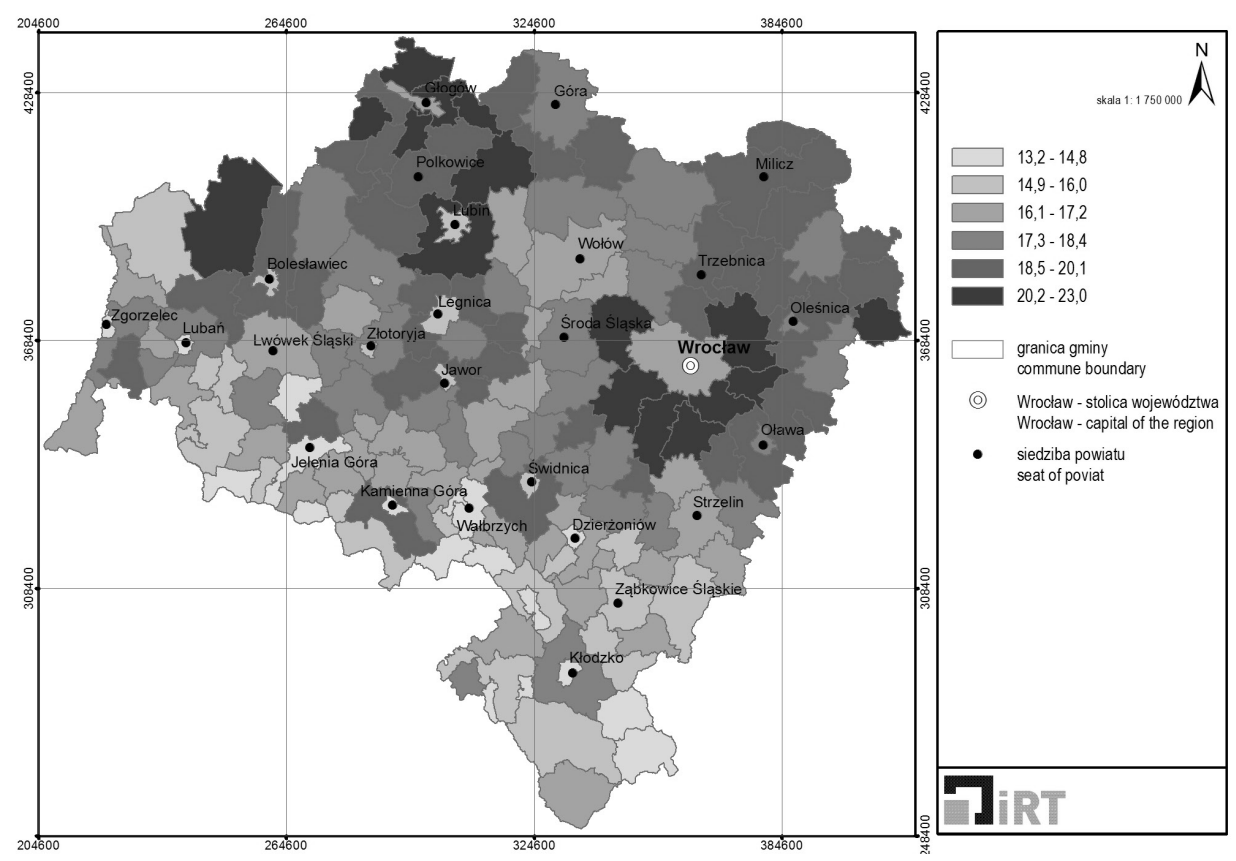

Ryc. 3. Udział ludności w wieku przedprodukcyjnym w gminach województwa dolnośląskiego w 2020 r. (\%) Share of population at pre-working age in communes of the Dolnoślaskie Voivodship in 2020, (\%) Źródło/Source: opracowanie własne/own elaboration. 


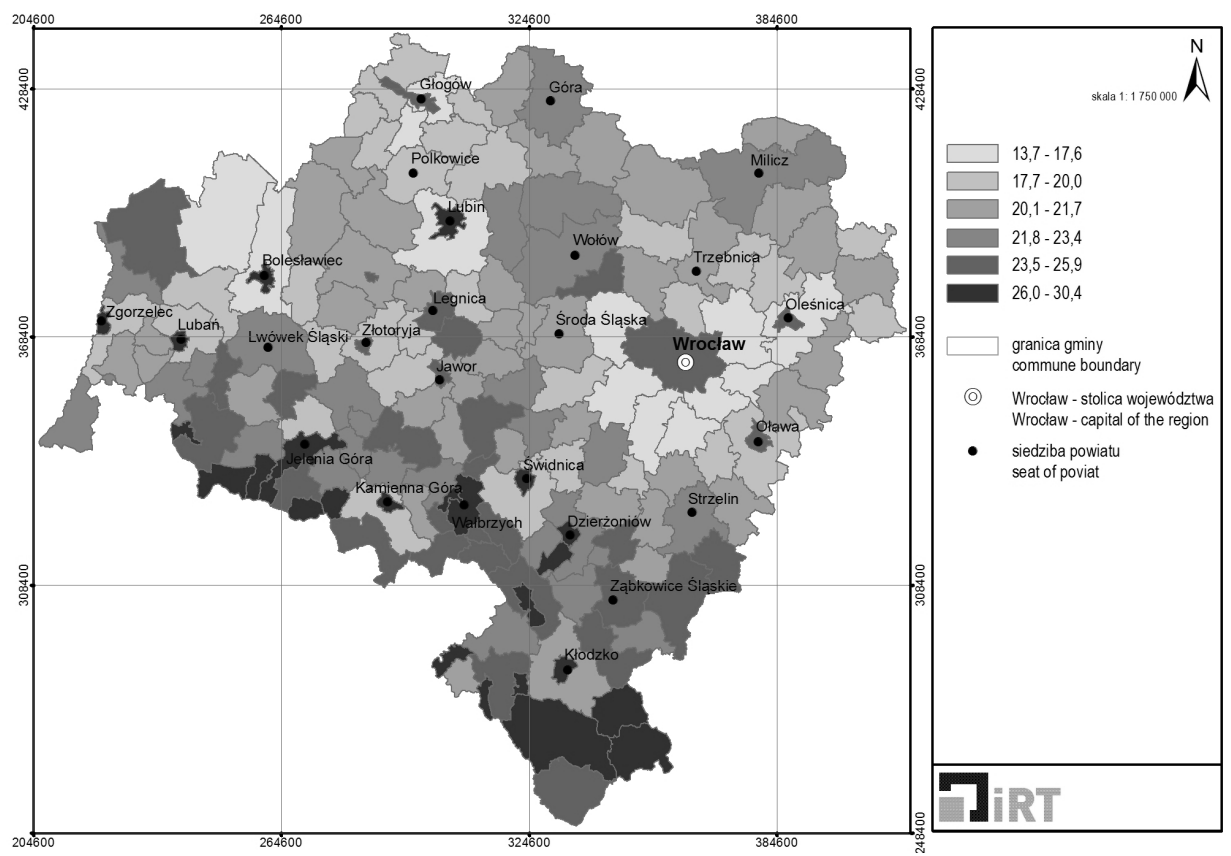

Ryc. 4. Udział ludności w wieku poprodukcyjnym w gminach województwa dolnośląskiego w 2020 r. (\%) Share of population at post-working age in communes of the Dolnoślqskie Voivodship in 2020 Źródło/Source: opracowanie własne/own elaboration.

\section{Literatura}

Brezdeń P., Górecka S., Tomczak P., 2012, Edukacja i rynek pracy Dolnego Ślq̨ska na tle uwarunkowań demograficznych, Rozprawy Naukowe Instytutu Geografii i Rozwoju Regionalnego Uniwersytetu Wrocławskiego, 22, Wrocław.

Holzer J.Z., 2003, Demografia, PWE, Warszawa.

Krzysztofik R., Szmytkie R., 2011, Studia nad procesami i strukturami osadniczymi sieci miast Polski Południowej, Prace Wydziału Nauk o Ziemi Uniwersytetu Śląskiego, 68, Uniwersytet Śląski, Sosnowiec.

Kurkiewicz J. (red.), 2010, Procesy demograficzne i metody ich analizy, Wydawnictwo Uniwersytetu Ekonomicznego w Krakowie, Kraków.

Mayer M., Szmytkie R., 2014, Kształtowanie się stref podmiejskich wokół miast średniej wielkości (studia przypadków z regionu południowo-zachodniego), [w] A. Jezierska-Thöle, M. Biczkowski (red.), Zintegrowany rozwój obszarów wiejskich w świetle polityki Unii Europejskiej, t. 2, Wielofunkcyjność obszarów wiejskich, Wydawnictwo Naukowe Uniwersytetu Mikołaja Kopernika, Toruń, s. 121-152. 


\section{Summary}

The aim of this paper is the analysis of population projection for communes of the Dolnośląskie Voivodship for the period of 2013-2020. It has been predicted that by 2020 the population of the province will decrease by 36.8 thousand inhabitants. The highest depopulation is expected to take place in major cities of the region, however the population of rural areas of Dolnośląskie will rise by 23.3 thousand. Rural areas of the voivodship are characterized by considerable diversification of trends in demographic changes: population increase in suburban communes, stagnation or population decrease in other communes. Spatial diversification of demographic trends will contribute to changes in population distribution. At the regional scale, growth of population concentration will be observed within the Wrocław Functional Area. However, considering local systems, a deconcentration of population (caused by suburbanization processes) is expected to take place. 
http://rcin.org.pl 